\title{
Children's services in the iron cage of performance management: street-level bureaucracy and the spectre of Švejkism
}

Wastell D, White S, Broadhurst K, Peckover S, Pithouse A. Children's services in the iron cage of performance management: street-level bureaucracy and the spectre of Švejkism

Int J Soc Welfare 2010: 19: 310-320 (C) 2010 The Author(s), Journal compilation (C) 2010 Blackwell Publishing Ltd and International Journal of Social Welfare.

Recent UK government reforms have introduced a range of measures to regulate practice in child welfare, with professional work increasingly structured into formal processes embedded in information technology. This prompts obvious anxieties about the erosion of professional discretion. Using Lipsky's concept of the street-level bureaucrat, we report on an ethnographical study examining how social workers organise their practice in an atmosphere of performance management. Clear indications of attenuated discretion are revealed, reflecting the shift to a managerial model of control. Of concern is the emergence of a pattern of formally conformant behaviour in which the letter of the organisational law is obeyed but without genuine commitment. Drawing on the anti-hero of Hašek's celebrated satire, we denote this form of passive resistance 'Švejkism'. While showing up the absurdities of excessive managerial power, such behaviours are ultimately dysfunctional for the organisation; an alternative governance paradigm, based on professional values, is briefly outlined.

\section{Wastell1', S. White'2, K. Broadhurst'2, S. Peckover ${ }^{3}$, A. Pithouse ${ }^{4}$}

1 Nottingham University Business School, UK

2 University of Lancaster, UK

3 University of Huddersfield, UK

4 University of Cardiff, UK
Key words: social work, children's services, information technology, street-level bureaucracy, Švejk, discretion, formalisation, New Public Management

David Wastell, Nottingham University Business School, Wollaton Road, Nottingham NG8 1BB, UK

E-mail: david.wastell@nottingham.ac.uk

Accepted for publication October 18, 2009

\section{Introduction}

The senior staff doctor came up close to Švejk: 'I'd like to know, you swine, what you're thinking about now?'

'Humbly report, sir, I don't think at all. ... I don't think because that's forbidden to soldiers on duty. When I was in the 91st regiment some years ago, our captain always used to say "A soldier mustn't think for himself. His superiors do it for him. As soon as a soldier begins to think, he's no longer a soldier but a dirty, lousy civilian. Thinking doesn't get you anywhere...",

The epigram is from Chapter 7 of Hašek's comic novel The Good Soldier Švejk, which provides a picaresque account of the fortunes of a Czech reservist called up to serve in the Austro-Hungarian army during the 1914-18 war. The excerpt shows a typical ploy of the book's eponymous hero apparently seeking to thwart the army's determination to have him declared fit for military service. Švejk is being interviewed by a panel of army doctors. By invoking the organisation's own proclaimed rules and values, he ingeniously shows disrespect and frustrates the bureaucratic process, as his superiors cannot easily argue against him without contradicting their own a priori positions. Švejk's artful capacity for outmanoeuvring Goliath-like authority, allied with his innocence and unquenchable spirit, make him an attractive anti-hero, and it is unsurprising that he has been adopted by contemporary writers as a symbol of covert resistance to excessive organisational power. Fleming and Sewell (2002: 859-860) used the term Švejkism to denote a battery of subversive tactics (scrimshanking, flannelling, feigned ignorance) based on 'disengagement':

... whereby the self is detached from the normative prescriptions of managerialism through irony and 
cynicism [thus] dissolving organisational power relationships in practical ways that also help to 'unmask' the ideological absurdities that shore them up.

Although Švejk's errant antics could as easily invite disapprobation as admiration, ${ }^{1}$ we cleave to a positive view of his organisational symbolism. Like Bailey (1993), we appropriate Švejk as an emblem of individualism in opposition to the totalising holism of the organisation. Distinctively, he does not challenge authority but obeys it in an ostentatiously literal way: 'flannelling makes a rule ridiculous, reduces it to absurdity, by obeying it mechanically as a machine would' (Bailey, 1993: 99). Withholding emotional commitment is an act of individual sovereignty, and in this sense Švejkism is a form of autonomy, paradoxically expressed through its opposite (conformance). In situations of significant power asymmetry, it is available as a defence of last resort. Comedy is also an essential ingredient. As a form of theatre, Švejkism needs an audience, whether real or virtual; its power to reveal the absurdities of the organisational regime (and hence destabilise it) provides the quintessential source of its comic effect, whether intentional or not. But such 'compliance without conviction' is problematic, as it cedes control to the bureaucracy, reproducing extant power relations (Fleming \& Spicer, 2003) and eroding the ability of individuals to influence outcomes. Švejkism may provide a humorous spectacle but hardly affords a model for effective practice, yet the performance-driven management systems currently being imposed on public services [the so-called New

1 It is natural to see Švejk as a lovable rogue, ingeniously outwitting the cack-handed agents of authoritarianism, but this romantic interpretation is in the mind of the reader. The Good Soldier Švejk is by no means a psychological novel; nowhere does Hašek disclose what Švejk really thinks or feels, or anything very much about his interior or antecedent self. We can only suspect concealed motives but are never told. On the surface, he strives always to do his duty, a model of obedience, not of misbehaviour. But his seemingly ingenuous determination consistently fails to achieve its aim. Even when dispatched to the front at the end of Part I, a series of hapless calamities (missed trains, navigational errors, mistaken arrests) means that by the end of the book he has still not reached his destination. 'Plain bloody hopeless' or 'hopeless with intent', as Stern (1966: 197) put the question. We never really know. Nor do we know if his lampooning is deliberate or inadvertent. This irreducible ambiguity is, of course, central to the book's moral subtext; indeed, it affords an enactment of it. Švejk's inscrutability provides an unbreachable defence against those more powerful forces that would seek to use him for their own ends. He protects his individual integrity through an impregnable privacy, a defence available to all of us in the face of oppression, however overwhelming. Ironically, Švejk's privacy continues to protect his inner self even from writers today who seek to co-opt him for their tendentious purposes. A symbol of heroic dissidence or a complete idiot? Svejk always remains his own man.
Public Management (NPM)] sadly beget its 'conditions of possibility'. Although Švejk shows the limitations of such managerialism 'to colonise the subjectivity of workers' (Casey, 1995: 161), the loss of professional agency nonetheless means that the ability of social workers to deliver the service they desire professionally, in the interests of their clients, has been compromised by the bureaucratic arrangements to which they are obliged to conform.

In this article, we will take up these general issues focusing on the exercise of discretion and the manifestations of 'resistance' among social workers in children's services in England and Wales at a time of increasing performance management and standardisation of procedures. To a significant degree, such formalisation has been facilitated by the pervasive implementation of a range of information and communication technologies (ICTs) transforming everyday social work practice, inevitably meaning more time is devoted to keyboard work in the office and less time in the field. A generic IT system known as the Integrated Children's System has been 'rolled out' nationally in the UK over the last few years (Broadhurst et al., 2009), which forces workers to follow the various steps specified in a formally defined 'workflow model' (see Figure 1). Such developments can in part be ascribed to the occurrence of a series of high-profile public inquiries into child deaths in England over the last 30 years, such as that of Victoria Climbie (Laming, 2003), leading to wide-ranging restructuring to remedy alleged flaws in decision making, communication and management oversight. The developments also reflect the wider currents of public service 'modernisation' alluded to above. At the time of writing, a 'social work task force' was being assembled by the UK government in the wake of the non-accidental death, following months of torture and abuse, of a boy aged 17 months known as Baby P. This is likely to recommend further reform. ${ }^{2}$

As a result of these various pressures, the government has introduced measures to regulate practice through proceduralisation and metrics. Process is now so standardised, particularly at the 'front door' where referrals from other agencies and members of the public are first received, that it may be argued that social workers are being invited (like our army friend) not to think outside of the workflows and standard dispensations. This has led some to argue that the discretion typically exercised by 'street-level bureaucrats' (SLBs) (Lipsky, 1980), so crucial to effective intervention, has become significantly curtailed. Here, we will review this debate, presenting data from our

2 See Statement from Secretary of State for Children, Schools and Families (Ed Balls). http://www.dcsf.gov.uk/pns/ DisplayPN.cgi?pn_id=2008_0253 (date last accessed 21 January 2009). 


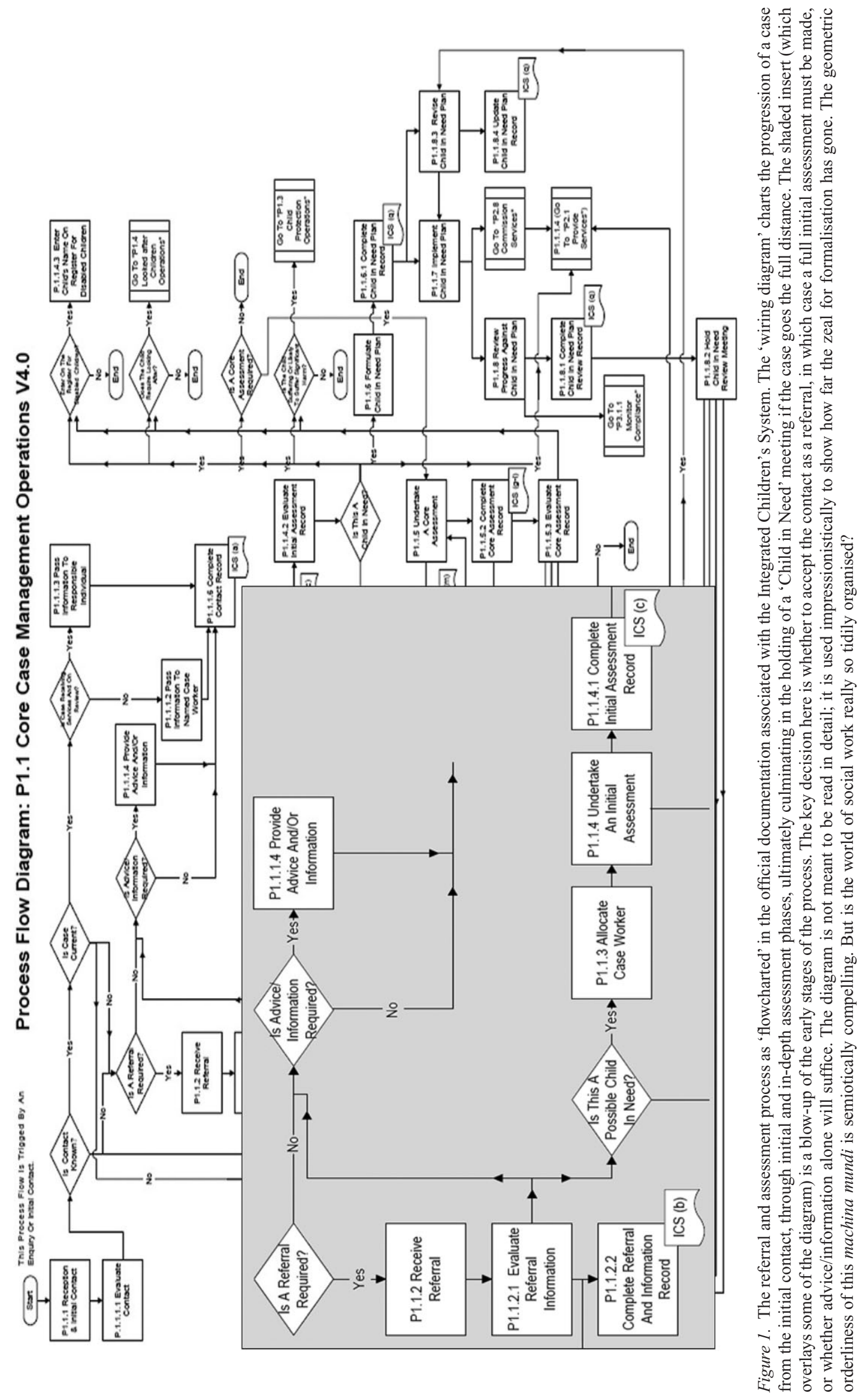


ethnographic fieldwork to examine processes of conformity and also local improvisation, in the form of 'workarounds' adopted to 'shake off' the procrustean constrictions of the workflow process. We shall be implicitly concerned with manifestations of Švejk-like organisational 'misbehaviour', including 'mutterings, grumblings and snickerings' (Erickson, 2004: 144), which (arguably) operate to reinforce threatened aspects of occupational identity and autonomy.

\section{Is the SLB still standing?}

The 'SLB' was first described by Michael Lipsky, a political scientist writing in the USA during the 1970s when there were serious cuts in public services (Evans \& Harris, 2004). Lipsky highlighted the work of teachers, police, social workers and court officials, but there has also been research on environmental inspectors (Fineman, 1998), day centre staff (Brandon, 2005), welfare officials (Meyers, Glaser \& MacDonald, 1998; Ruccucci, 2005) and vocational rehabilitation counsellors (Maynard-Moody \& Musheno, 2000). Lipsky's work draws attention to the practical fact that front-line workers have considerable discretion in carrying out their work, and their everyday practices might thus depart from what managers and politicians expect of them. In their mundane encounters, they effectively decide what policy is:

The decisions of street-level bureaucrats, the routines they establish and the devices they invent to cope with uncertainties and work pressures effectively become the public policies they carry out (Lipsky, 1980: xii).

Operating within rules that never quite fit the singularity of local circumstances, the SLB is obliged to make sense of the directives, rules and procedures as they apply to the individual case. Indeed, such discretion is essential in order to get the job done: 'the situations they face are too complex to reduce to prescribed responses' (Evans \& Harris, 2004: 878). In terms of cybernetics, this is simply a reflection of the ineluctable writ of the Law of Requisite Variety, coined by the British psychiatrist W. Ross Ashby (1956). Discretion is not some incidental feature; it is fundamental to the operation of any 'viable system'. Imagine a system (e.g. a family) to be 'controlled' in the sense that we seek certain desirable outcomes (e.g. children do not suffer harm and they achieve their full potential). Variety simply denotes the number of different 'states' that the system can be in, which, in the case of a human system (e.g. a family), is large and dynamic. All families are different, and the social care system must therefore possess a comparable degree of internal variety (repertoire of responses) in order to deal effectively with the 'input variety'. Pithily, the Law proclaims:
'Only variety absorbs variety' (Beer, 1994: 286). This, of course, is the exact opposite of the principle of standardisation, which in the limiting case, provides for the same institutional response whatever the input! Rules, policies, and procedures are all abstractions and intrinsically lack variety; intelligent human agents provide the necessary 'variety amplifiers' (Beer, 1994) that enable them (the rules etc.) to be applied effectively.

Pithouse (1987) memorably described social work as an 'invisible trade'. The SLBs are the main link between the client and the organisation, and they are rarely observed in their work. As Hudson (1989: 44) noted: 'Policemen decide who to arrest... teachers make subtle decisions on who is teachable; social workers on who is socially salvageable...' The formalising tendencies inherent in NPM thus pose a significant challenge to the SLB, enabling managers to usurp their essential discretion through increased audit and procedural control embodied in mandatory ICT systems. This tension has been recently examined by Evans and Harris (2004), drawing on Howe's (1991) critique of Lipsky. The situation, they argue, is not one of simple 'curtailment', but there are 'gradations of power' between managers and professionals, and that discretion is not 'an all-or-nothing phenomenon' (Evans \& Harris, 2004: 881). They describe a 'weaker sense of discretion' as 'the interpretation of and authority to decide within the rules' (p. 882). Evans and Harris provide examples from community care where rules have to be interpreted and can be flexed to meet user need.

At this point, the Good Soldier enters the fray. In the opening section, we articulated our anxiety that the strengthening of managerial control in contemporary public services creates the conditions for Švejkism to take hold. Faced with over-weaning organisational power, 'compliance without conviction' affords the final option for the exercise of individual sovereignty, and by providing comic opportunities for satirising the oppressive regime, it also gives palliative relief. But the power to execute the professional task has nonetheless been eroded. With remarkable prescience, Lipsky discussed the impact of performance management on SLBs, and his observations have enduring pertinence for the present day. We end this section quoting from a discussion to which Lipsky devoted a full chapter:

Job performance in street-level bureaucracies is extremely difficult to measure. The many implications of this statement include the facts that these agencies are not self-corrective, and the definition of adequate performance is highly politicised. . . It is not only that human beings are complex and that a metric of correct responses is inappropriate. Equally important, there is rarely any way to determine on a regular basis what would have happened to clients 
in the absence of intervention.... Despite the difficulties of performance management, street-level bureaucracies do seize on some aspects of performance to measure as a means of exercising control. In turn, the behaviour of workers comes to reflect the incentives and sanctions implicit in those measurements (Lipsky, 1980: 48-51).

\section{The fieldwork}

As Thomas and Davies (2005) noted, the ways in which NPM plays out in everyday contexts have been underexplored empirically. The present research can be seen as a response to this. We have raised a range of concerns regarding the possible curbing of professional discretion in child welfare, and the aim of our work is to investigate the empirical reality of these anxieties. Our research methodology broadly follows a phronetic ${ }^{3}$ approach (Flyvbjerg, 2001), seeking to move beyond pure social description to generate practical insights for enhancing organisational design; in simple terms, to improve things. Using ethnographic methods, we have attempted to identify cases-in-context that reveal the adverse influence of structural conditions on situated practices. Our work has enabled responses from different agencies to similar work pressures to be studied, focusing particularly on processes of conformity and resistance.

The fieldwork, involving five children's services directorates in England and Wales, began in early 2007 and is still underway. The sites will be referred to by the following pseudonyms: a London borough (Metroville), a large county council (Shire), a metropolitan borough in England (Westford), a unitary authority (Seaton) and a rural authority (Valleytown). The ethnographies have involved participant and nonparticipant observation of management and practice in key decision-making loci, such as the duty desk, the social work 'referral and assessment' teams, strategy and review meetings. Interviews and focus groups have taken place, exploring the ways in which practitioners and managers negotiate the systems and protocols, respond to referrals, make decisions about priorities and interventions, and so forth. Documentary analysis of electronic case records and paper files has also been undertaken.

We have paid particular attention to the 'front door' practices in our sites, as here work is particularly circumscribed by government-led performance criteria following the implementation of The Framework for the Assessment of Children in Need and Their Families (Department of Health, 2000). This defined the initial

\footnotetext{
3 Roughly translated as 'practical wisdom', contrasting with the two other forms of knowledge distinguished by Aristotle: episteme (scientific knowledge) and techne (craft skill).
}

statutory response to a 'contact' or 'referral' as a distinct stage in the assessment process and deemed that assessment must be undertaken within specific time frames. The framework introduced performance timescales: within one day of a referral being received, agencies must decide what response is required, and within seven days an initial assessment (IA) must be completed. Figure 1 provides a flow chart of the process in full.

Following the IA, cases may proceed to a section 47 (child protection) investigation (Children Act, 1989) because the child appears to be at immediate risk of significant harm, or a more detailed 'Core Assessment' (CA) of the child's needs may be undertaken (within 35 days) with a view to in situ family support. The forms associated with these assessments have been standardised nationally, and we have found very limited regional variation. The dominance of ICT means that child welfare workers are constrained by a number of 'e-pathways' - work cannot be done unless there is an electronic system to monitor and direct it. The workers thus have to decide which e-pathway to deploy very soon after they receive information from referring agencies. This intersects with the more conventional form of case categorisation. Thus, if significant curtailment of discretion has obtained in pratice, we may reasonably expect to find it in this carefully mapped terrain.

\section{Findings: tales from the trenches}

\section{Tamed by technology? Curtailment in local contexts}

The metrification of the referral process described above results in the publication of performance indicators that are scrutinised at multiple levels by team managers, senior local authority staff, local politicians and national government audit. The results are publicly available and inform 'star-ratings' for local authorities. We have found that references to 'percentages' are commonplace across our sites, exercising team managers in referral and assessment teams particularly. Statistics on the number of assessments completed to timescale are used to measure efficiency and effectiveness. We can see in the extract below how potent these performance imperatives have become. One of the research team has rung Felicity French (pseudonym for the Quality Assurance Manager, Seaton) to confirm a meeting the following day. The fieldnote records:

Felicity French a bit cagey - she said that they had all been called into a meeting that morning with the manager. The manager, $D D$, was very annoyed and giving them all a bit of a 'dressing down' about the state of affairs in IA. They have missed the performance indicator this week for the per cent of IA's 
being done within 7 days and missed it by a lot. $D D$ is very annoyed, she has been on sick leave herself for two weeks and has come back to find that workers have been slacking behind her back.

This team is under extreme day-to-day pressure with a very high referral rate compounded by high staff turnover. The extract shows clearly how the performance indicators are inexorably driving practice, eliminating any slack that might alleviate pressure or allow more considered decision making, and generally contributing to the obvious stress felt by staff at all levels. The extract shows that adherence to performance targets has become imbued with strong normative significance and has become part of organisational talk.

A further impact of the performance management system has been the deployment of customer relations managers to take and enter referral data at the point of contact. At its most extreme in Shire, this takes place in a centralised 'contact centre' dislocated from the children's services department. Operated entirely by administrative staff, this system appeared to create more work for front-line social work teams, as the following extract from a team manager in Shire illustrates:

Manager: We have in excess 300 referrals a month with 5 social workers and we are very, very busy. So we need that admin support to be able to put them on. Prior to the contact centre, we used to have a customer care person sitting in the room with the social workers who used to deal with all the referrals that came through to our team. That, in my opinion, was a much better system than the contact centre... the customer care person had access to the social workers, who they could also direct a lot of questions to and we didn't have to respond to everything, we could direct families to appropriate services.

Researcher: So what was the rationale then for kind of centralising of referrals?

Manager: You'd have to ask higher management that.

The contact centre in Shire has curtailed professionals in other ways as well. The imperative to be able to direct calls to social workers means that they must complete a diary sheet detailing when they will be in or out of the office. If the social worker is not at his or her desk at the time stipulated and thus unable to take a call from the contact centre, he or she receives a red light. After three red lights the social worker may be called to account. It is not just the social work teams who feel the negative impact of centralised 'contact' systems; the following extract from an interview with a customer relations worker in Seaton illustrates the stress and its impact on the call takers:
Admin. worker: The phone will be ringing continuously; you put the phone down and it rings straight away... and your mind just gets frazzled, I might have written 5 or 6 pages of A4 paper... and when I come back to reading them, it's all looking a bit messy... I can't quite make out what I've got down.... Sometimes I can't even get out of my seat ... the phone is permanently ringing. . . . And if someone brings me a pile of faxes and the phone starts ringing again... I can't even skim them to see if there's something that is going to be missed...

The contradictions of placing the 'cheapest' employees as information receivers were anticipated by Lipsky (1980: 198) some 30 years ago:

To serve more clients, legal services offices often train receptionists to discover quickly the reason for a potential client's inquiry, and then refer the caller to a trained para-professional. ... For the system to work well, the receptionist should precisely follow the guidelines for referral. Two problems arise.... First, it is extremely difficult to circumscribe all possibilities. Second,... the presenting problem may only be the client's most urgently felt concern. The client may have more pressing problems, but he or she is not aware of them or aware that assistance may be available.

\section{Roundabouts and workarounds}

However totalising the demands of timescales and targets, our data suggest that there are limits to the power of technology to control practice, i.e. that workers are not so easily tamed! The simplest forms of resistance involve social workers lampooning the absurdities created by imperfect ICTs, as this example from Metroville shows:

Social Worker: I have a dreadful case where there were 6 children and 5 fathers and I couldn't work out who was who, so I had to go to mum and pretend that I was really stupid. ... And I said I really don't understand it who is this?, who is that? ... And she wasn't living with any of the fathers but the computer had her down as living with one... so there was quite a few changes with people in the wrong addresses, like I say, a 7- and 5-year-old that the computer said were living on their own!

Because of these pressures and the frustrations of the timescales imposed at the IA phase, workaround practices have evolved to 'extend' the time window. In our view, these are often driven by concerns to serve the interests of children and families and undertake a 'better' assessment than the formal processes will allow. The following example (from Shire) shows dramatically how technology was well and truly tamed. By 
redefining assessment as the point at which the professional appraises the circumstances of the child rather than the production of a document, the tyrant-process is brought into line to support responsible practice.

Social worker: ... so if it [the referral] comes in on Tuesday and it's allocated to me, if I'm not on duty till the Friday, I wouldn't go out until Friday, because you have to have time to send the letter. Basically they 'outcome' it the day you see the child, not when you've done the assessment [emphasis added] so if I see that child the following Tuesday, it would be outcomed that day, signed off as complete that day.

Researcher: so it's signed off the day you see the child, not the day you complete the form?

Social worker: Certainly not the day I complete the form, because that could be 3 weeks later... because actually that keeps it within timescales, if they sign it off on the day that you've seen the child, because they're putting the visit in, within the 7 days you've seen them, then that's when it is.

Another useful workaround is to invent spaces between the e-pathways. As explained above, on completing the IA, a decision is made as to whether a case should be closed or progress to service delivery or to a more detailed CA. This timescale is also a national performance indicator. In Metroville, all deadlines for assessments are monitored electronically by the client record system. The system highlights if particular boxes are incomplete and must be electronically signed off by the manager to meet the deadline. At the beginning of our fieldwork, a workaround had been established that if an IA was proving difficult to complete in seven days, the worker was able to transfer the case to a CA simply to enable more time, not necessarily because a more thorough assessment was needed. However, an external audit subsequently commented on the large number of CAs being done! Anxious to avoid criticism, there was an instruction from senior management to reduce the number of CAs. This was managed by inventing a new process category, Review Initial Assessment. This enabled the IA to be signed off after seven days even if particular tasks were incomplete.

\section{Enter the Good Soldier Švejk!}

The workarounds described above were devised to ensure the wellbeing of children and their families in the light of complex casework that frequently defies procedural standardisation. But for every example of benign extemporisation, there are counter-examples where the pressure to obey the all-powerful machine is compromising the ability of professionals to practise as they think best, leading to serious concerns about the fitness-for-purpose of the organisations they 'serve'.
Shire, with its Contact Centre, provides a particularly apposite example. The excerpt below shows how this new structure is being exploited by professional staff to make their life easier, seemingly at the expense of the clients. Of course, nothing wrong is being done; council policy is simply being followed by routing all 'customer interactions' through the 'proper communication channels'. To do otherwise would be to violate organisational policy! This fieldnote refers to a conversation with the manager of one of the social work family support (longer term) teams in Shire.

The manager told me the office is now really quiet, phones used to be ringing all the time-now he can easily be unobtainable, enables workers to get on with work - but [laughing] not so great for families who want to make contact. He said a lot of people will trying ringing through the Contact Centre and will hang up or don't bother to leave messages if they do get put through... although the workers love it - it's not really having the desired impact on making service more accessible - but he knows there's no way the local authority can backtrack now the Contact Centre is set up and workers have all to be redeployed etc. He said even if a service user comes into the reception, the reception worker can't call upstairs for the social worker, the reception worker has to call the Contact Centre and be asked to be put through the 'proper communication channels' (Fieldnotes, Shire, May 2008).

We have pointed to the immutable timescales associated with IA. This often leads to the production of contingent new rules, which recall some of the bureaucratic absurdities so ridiculed in Hašek's novel. In both the following examples (from Shire), the behaviour of superiors is commented on by front-line staff with (one intuits) barely disguised scorn:

Senior Practitioner: We get emails from managers saying not to make any more allocations ... team leader has been NFA -ing [No Further Action] a lot and trying to reduce contacts because we are told there are too many in the system . . the team leader said to deal with all referrals as contacts unless they need allocating ...

Social worker: My new manager . . she comes back and says, it [the IA] doesn't say have you seen the child, it says 'has the child been seen?'; you can put 'yes' and then make it clear that the teacher has seen the child. I thought hmm, I bet the teacher saw Victoria Climbie [high profile child death] as well, you know, what's the point of me even doing an assessment if I haven't seen the children.

The risible absurdities that compliance with the new organisational order begets are well illustrated in the final two vignettes. The first is drawn from an interview 
with two experienced social workers in Metroville. The humorous vein running through the excerpt clearly shows their detachment from the imposed regime; hilarity mounts during the first worker's remarks, before the seriousness of the situation breaks through in her colleague's poignant rejoinder regarding the impact on their practice. Although the Švejkism in these excerpts is striking, we should reiterate that we are not implying that the workers are by any means flannelling or not endeavouring to do their jobs professionally. We use the term specifically to denote manifestations of disengaged but obedient behavior produced by obligatory conformance with the bureaucratic regime which reveal the absurdity of the imposed systems and processes.

First social worker: The five outcomes ${ }^{4}$ came in and instead of being creative they just stuck it on the end [of the form] ... [both laugh] ... and they just appeared. ... You don't have an analysis with your recommendations, your recommendations are the five outcomes [laughter] ... so you don't have a box where you explore what you've written and analyse it and gather it all together and write why you've made the decisions you have... you write the 5 outcomes, strengths, weaknesses and risks under each thing, and then your analysis and recommendations are strengths, weaknesses and risks without a box for saying why...

Second social worker: I feel like a robot, because you feel you're just like splurting it out . . you're just putting information on a form, it doesn't feel like you are actually being required to provide your professional opinion in a holistic kind of way, it doesn't really help I think...

The second vignette, from Shire, illustrates two further manifestations of organisational dysfunctionality. The social worker begins by contrasting the herculean efforts that the bureaucracy requires to set up a 'Child in Need' conference with the mundane, generic nature of the service that is ultimately provided. She then goes on to describe how formalisation of the organisation has created internal divisions that would seem to undermine the agency's ability to function effectively and to deliver the services required of it.

Social worker: ... because if you do instigate a service, well you start with contacting all the agencies, health education, any community nurses... alcohol rehab, police, anybody involved with the family...you chair the meeting and take the minutes at the same time... and it could all be

4 The five outcomes are official government policy, providing an overarching framework for social policy regarding children and families. See Every Child Matters, Chief Secretary to the Treasury (2003). just for half hour a week for behaviour input only for a child, and that's for any service, there's no shortcuts ... then the family support centre will do with 6 weeks intervention... and hopefully it will then be closed, they've had the intervention, but it's very generic, it's actually laughable rubbish... And you fall into this language... [with] family support it will be 'maintaining boundaries' - and you think what the bloody hell does that mean - you know family support have got a bit of work that they know how to do and nobody ever phoned up and said, 'What exactly do you want me to do with erm this family'- maintaining boundaries [laughing very loudly] ... I don't know how the social workers got to this point - but they refused to take calls from the family centre because 'they've had the plan, they've attended the meeting, how dare they ring with such a trivial question'.

\section{Professional argot: re-enter the SLB?}

Notwithstanding the encroachment of managerial technology, social workers continue to exercise their professional discretion through categorisations, 'diagnostics' and the social sorting of children and families. Professional identities are sustained and bureaucratic imperatives 'resisted' by various forms of sometimes florid story telling using a professional argot that emphasises the 'real work' that almost by definition remains beyond the bureaucratic gaze. Street-level language gives the power to define, reaffirms the invisible trade and reinforces occupational identity while at the same time rattling the cage of the rule-bound bureaucrat. In the extract below, we can see the use of selfconsciously anti-bureaucratic language:

Adolescents are difficult because they do not always get the service they deserve ... if they are breathing, fed, clothed, got money in their pockets and a $B \& B$, I will say, 'That's it, see you in another life'.... Really, these cases need more care. . . The life skills they would have got from their parents. But I can't do that. I've got a baby in a crack house. I've got to deal with that. But I know this is something we should be able to provide a service to. This is my next generation of parents (Team Manager, Valleytown).

The team manager is referring to the bureaucratic imperative to ration resources, but she does so by making use of a subtly irreverent 'street-level' vernacular that invokes the real work. Adolescents are considered as 'deserving', but resource constraints, together with judgements about their 'risks' and/or 'needs', mean that such cases are unlikely to be prioritised. The manager contrasts the limited service that is provided for adolescents with the riskier situation represented by the lurid description 'baby in a crack house'. The moral 
dilemma facing the social worker is evident, as clearly both types of cases would benefit from a service. The florid categorisation of a 'baby in a crack house' is potent and compelling; by trumping the 'teenager in trouble', it removes at a stroke any ambiguity about priorities. This kind of graphic phraseology is a common feature of case-talk in social work settings (Hall, 1997; White, 1999) and is manifestly not easily amenable to command and control. ${ }^{5}$

\section{Discussion and conclusions}

If one imagines perfect holism, the only experience that is allowed to influence collective decisions is the experience of those who dominate. The remedy is individualism ... Švejks are different. They are not vulnerable to the holistic virus. . . They are the ultimate individuals, both living off and defying the organisation, not only in their own material interest but also that they may have the freedom to shape their own identities and bestow their services where they think best. Formal organisations want holism unthinking consent - but, if they achieve it, cannot effectively adjust themselves to an ever-changing environment (Bailey, 1993: 216-217).

As Evans and Harris (2004: 891) stated, care should be taken 'not to confuse the presence of rules with determinacy'. Their examination of the impact of managerialism on discretion injects a welcome degree of nuance in a debate where the concept of discretion has typically been used as an 'all-or-nothing good thing'. As we have noted, Evans and Harris (2004) traced out a range of forms of discretion, along a primary dimension that runs from weak (authority for interpreting/applying a rule, within a defined procedual framework) to strong (both the decisions and the criteria for making those decisions are in the hands of the professional). Writing around six years ago, there is a sanguine tone to their assessment: reports of the "death of discretion' would seem to have been much exaggerated, in their opinion. Rather than curtailment, they see a shift in the balance of power towards managerial control, but not the final elimination of professional power. The nebulousness of policy is a factor, but the proliferation of rules in itself would perversely seem a source of hope; more rules and guidelines generate more need for their interpretation. The SLB was adjudged to be alive and kicking even if the kicking was against the traces!

5 There is, however, a downside. Although it allows the work to be done, rationalising the decision to provide a service or not, it may also threaten safe practice. In a recent overview of 116 Serious Case Reviews (reviews of child deaths and serious injuries thought to be associated with abuse or neglect), Brandon et al. (2008) note that 25 per cent were over 11 years, including 9 per cent who were over 16 . Being a teenager does not provide a guarantee of safety.
Our findings are less optimistic and wear the authority of a thorough empirical grounding in the lived world of contemporary social work. The pace of modernisation has continued unabated over the intervening years; the amarmentorium of performance management has expanded and taken a stronger hold; ICT is all pervasive and targets have proliferated, remorselessly bringing more of the 'invisible trade' into its cross hairs. Weak and strong discretion are not commensurable versions of the same concept; more of the former does not balance out less of the latter. We have focused our work on the analysis of intake processes, where formalisation is necessarily most developed. We argued that this locus provides a critical point at which to test the curtailment thesis. Although our findings reveal a more complex picture than the 'curtailment' polemics suggest, they overwhelmingly paint a picture of procedures and rules (inscribed in ICTs) that increasingly constrain what can be done, and indeed determine behaviour in the sense that power is ceded to the rules. Anxieties about the encroachment of Švejkism seem to be bourne out by our findings.

Hegemony has been defined as an acceptance by those who are ruled that their subjection is part of the natural order of things (Bailey, 1993). Is it alarmist to begin to speak in such terms? Professionals have their own goals - professional and personal - and consequently their own prejudices. Lipsky (1980: 201) saw SLBs as idealistically motivated to help services users. Others have seen professionals as actuated mainly by self-interest (Hudson, 1989), and the experience of the last 20 years has seen increased attempts to control professional practice. There may be something to this argument, but there are legitimate grounds for anxiety that the imposition of bureaucratic control may have gone too far and may already have become seriously counterproductive. Shortening the traces is likely to engender more and more Švejkism as workers become increasingly estranged from the goals of the organisation and the professional task. The following quote from an experienced team leader in a site outside our main research study poignantly captures the 'slippery slope' moment when street-level bureaucracy starts to give way to Švejkism:

I used to tell my social workers to get the work with the family right, and then recording lags behind... but I've been told I've got to stop that. So, I've had to say, cut your visits down, keep to 45 minutes and don't write so much. We've always resisted but we've come to the point where we've got to compromise practice, to devalue it because of the fear of spot inspection.

This is the tocsin for those hell-bent on the NPM project. The Iron Cage may work well in the zoo, but social work is not a zoo. Švejk is the personification of 
the alienated employee, of an individual serving in an organisation without much serving it (adapting a handy phrase from Bailey, 1993: 9). Although this is clearly far from ideal, perhaps the real worry is not that managerialism fails to control the individual, but that it may ultimately succeed, resulting in a docile workforce of 'designer employees' (Ackroyd \&Thompson, 2003; Casey, 1995) entirely in thrall to the hegemony of the internal regime rather than the professional task. A dystopian vision to be sure. As Bailey wrote (1993: 104): 'A fearful stillness characterises an overgrown bureaucracy achieved by a quiet rejection of the organisation's obligation to stay in touch with reality'.

While Švejk is an attractive folk-hero, we cannot look to him as a reforming force, the slayer of the NPM dragon. Švejkism certainly contains the grim hope that left to its own sclerotic devices, the dystopian bureaucracy will collapse of its own accord, akin to wooden structures outwardly intact but internally infested by the teredo worm! But Švejks are disengagers, intent not on toppling the status quo but on survival in an absurd world. 'Yield and overcome' 6 does not guarantee the desired consummation, and conformance to the irresistible force is both stressful for social workers as professionals as well as dysfunctional for the organisation as a whole. Social care cannot function as a system without an engaged professional workforce, exercising practical wisdom (phronesis again). The Law of Requisite Variety tells us this, and the SLB is the living embodiment of this necessary principle. Of course, there are other ways of bringing the morality of the professional and the organisation into alignment, of balancing autonomy with corporate orderliness. Rather than pressing ever more urgently the cause of bureaucracy over professionalism, salvation surely lies in reversing the direction of travel, of relaxing rather than tightening control. Indeed, this is the direction suggested by the research evidence. While setting targets and goals can improve performance, doing so in a participative way is well known to be more effective than imposing them by fiat, especially for complex, uncertain tasks that cannot readily be routinised (Locke \& Latham, 2002). It would seem perverse to ignore this evidence.

There are certainly more effective ways of effecting public sector reform than the top-down model in which a remote elite formulates policy and implements this by diktat, treating professionals as compliant actors. Policy objectives, however laudible, rely on the responsible use of professional judgement by committed staff

6 See Tao Te Ching, Chapter 21 (translation by Addiss and Lombardo, Hackett Publishing, Indianapolis, 1993). Other sections are relevant too, see Chapter 58 , for instance. In the same translation, this begins: 'If government is muted and muffled, people are cool and refreshed. If government investigates and intrudes, people are worn down and hopeless!' if they are to achieve their intended aims, and are fatally undermined if this is withheld by Švejkist fauxcompliance. As Hubbard, Mehan and Stein (2006: 240) wisely noted, 'implementation dominates outcome' in the policy world. Reform-as-learning provides an alternative approach based on co-construction and mutual learning and has been shown to be efficacious in the educational domain (Hubbard et al., 2006) where top-down methods have failed. Lipsky also suggested a more collegial approach involving the promotion of professional values and their incorporation into policy. A final quote from him would seem a fitting way of rounding off this article:

If street-level bureaucrats cannot be restricted in everyday functioning, then self monitoring must substitute for bureaucratic controls. To this extent, the advocates of greater professionalism in streetlevel bureaucracies appear to have an unassailable point (Lipsky, 1980: 201).

\section{Acknowledgement}

This research was supported by the ESRC's Public Services Programme, grant reference: RES-166-25004.

\section{References}

Ackroyd S, Thompson P (2003). Organisational misbehaviour. London, Sage.

Ashby WR (1956). An introduction to cybernetics. London, Chapman and Hall.

Bailey FG (1993). The kingdom of individuals: An essay on self-respect and social obligation. Ithaca, NY, Cornell University Press.

Beer S (1994). The heart of enterprise. Chichester, Wiley.

Brandon M, Belderson P, Warren C, Howe D, Gardner R, Dodsworth J, Black J (2008). Analysing child deaths and serious injury through abuse and neglect: What can we learn? A biennial analysis of serious case reviews 20032005. London, Department for Children, Schools and Families.

Brandon T (2005). Empowerment, policy levels and service forums. Journal of Intellectual Disabilities 9(4): 321-331.

Broadhurst K, Wastell D, White S, Hall C, Peckover S, Thompson K, Pithouse A, Davey D (2009). Performing 'initial assessment': Identifying the latent conditions for error at the front-door of local authority children's services. British Journal of Social Work 1-19. British Journal of Social Work Advance Access, published 18 January 2009.

Casey C (1995). Work, self and society: After industrialism. London, Routledge.

Chief Secretary to the Treasury (2003). Every child matters. London, The Stationery Office.

Department of Health (2000). Framework for the assessment of children in need and their families. London, The Stationery Office.

Erickson F (2004). Talk and social theory: Ecologies of speaking and listening in everyday life. Cambridge, Polity Press.

Evans T, Harris J (2004). Street-level bureaucracy, social work and the (exaggerated) death of discretion. British Journal of Social Work 34(6): 871-895. 


\section{Wastell et al.}

Fineman S (1998). Street-level bureaucrats and the social construction of environmental control. Organisation Studies 19(6): 953-974.

Fleming P, Sewell G (2002). Looking for Good Soldier Švejk: Alternative modalities of resistance in the contemporary workplace. Sociology 36(4): 857-873.

Fleming P, Spicer A (2003). Working at a cynical distance: Implications for power, subjectivity and resistance. Organization 10(1): 157-178.

Flyvbjerg B (2001). Making social science matter: Why social enquiry fails and how it can succeed again. Cambridge, Cambridge University Press.

Hall C (1997). Social work as narrative: Storytelling and persuasion in professional texts. Aldershot, Ashgate.

Howe D (1991). Knowledge, power and the shape of social work practice. In: Davies M, ed. The sociology of social work, pp. 202-220. London, Routledge.

Hubbard L, Mehan H, Stein MK (2006). Reform as learning. New York, Routledge.

Hudson B (1989). Michael Lipsky and street-level bureaucracy: A neglected perspective. In: Barton L, ed. Disability and dependency, pp. 42-54. London, Routledge.

Laming (2003). The Victoria Climbie inquiry: Report of an inquiry by Lord Laming. Norwich, The Stationery Office.

Lipsky M (1980). Street-level bureaucracy: Dilemmas of the individual in public services. New York, Russell Sage Foundation.
Locke EA, Latham GP (2002). Building a practically useful theory of goal setting and task motivation: A 35-year odyssey. American Psychologist 57(9): 705-717.

Maynard-Moody S, Musheno M (2000). State agent or citizen agent: Two narratives of discretion. Journal of Public Administration Research and Theory 10(2): 329-358.

Meyers M, Glaser B, MacDonald K (1998). On the front lines of welfare delivery: Are workers implementing policy reforms. Journal of Policy Analysis and Management 17(1): 1-22.

Pithouse A (1987). Social work: The social organization of an invisible trade. Aldershot, Ashgate.

Ruccucci N (2005). How management matters: Street-level bureaucrats and welfare reform. Washington, Georgetown University Press.

Stern JP (1966). On the integrity of the Good Soldier Schweik. Forum for Modern Language Studies II(1): 14-24.

Thomas R, Davies A (2005). Theorizing the micro-politics of resistance: New Public Management and managerial identities in the UK public services. Organization Studies 26(5): 683-706.

White S (1999). Examining the artfulness of risk talk. In: Jokinen A, Juhila K, Poso T, eds. Constructing social work practices, pp. 87-100. Aldershot, Ashgate. 